\title{
On the way to Gigapolises: can global urban development become sustainable?
}

\author{
M. Keiner \& W. A. Schmid \\ Institute for Landscape and Spatial Development, ETH Zurich, \\ Switzerland
}

\begin{abstract}
Urban growth in developing countries is a challenge to the management capabilities of national and local authorities. Problems of steering the urban development occur not only in 'mega-cities' but also in smaller but rapidly growing cities. Will the big cities continue to grow, will they become ungovernable gigapolises? Sustainable urban development is a must and early action is needed.

In research, the issue of hyper-growing sub-mega cities in the developing world has not yet been analyzed sufficiently. Those cities can be characterized by rapid population growth, an economy dependent on the informal sector, widespread poverty, widespread informal housing, basic environment and public health problems, and governance problems. These problems are similar to those of the mega-cities; yet offer the opportunity for earlier intervention. Meeting the needs for the city's inhabitants of today and to improve the quality-of-life of future generations is of major concern. The prerequisites for sustainable urban development are 'good governance', i.e. the democratization of planning decisions by enhancing participation of individuals, households, communities, voluntary associations and NGOs; decentralization; networking of cities with similar challenges regarding sustainability; the elaboration of sustainability oriented strategies and visions; harmonizing planning instruments and regulations; using indicator based monitoring to control and to enforce sustainability related planning measures
\end{abstract}

Keywords: urbanization, mega-cities, gigapolis, sustainability, good governance. 


\section{Introduction: urbanization without limits?}

The world of today is urban and will tomorrow be even more urban. Until 2030, the UN Population Division expects that in Africa, the share of population living in cities will rise from $37 \%$ in 2000 to an estimated $53 \%$ in 2030 , and in Asia, the same figures will mount from $48 \%$ to $54 \%$ during the same period of time. Thus in 2030, 3.8 billion people will live in urban areas in developing countries, compared to 1.4 billion in 1990 [1]. This means that $80 \%$ of global growth of the urban population will take place in the poorer countries, and from 2000 to 2030 , the urban population in developing countries will grow by 60 million people a year, effectively doubling in the period from 2000 to 2030.

The reason for this 'Big Bang' is a population explosion linked to tremendous rural-urban migration processes and the striving of people for an improved quality of life in a globalizing world [2]. In general, in the world's poorer countries, socio-cultural innovations, economic growth, diversification of income opportunities, and new patterns of self-determination of the individual are limited to the big cities. These attract more and more people and, by causing a drain of brain and labour force from the countryside, enlarge the urban-rural gap $[3,4]$.

Global urbanization has resulted in so-called 'mega-cities', which are cities with 8 or 10 million or more inhabitants. Today, according to different sources and spatial delimitations (cities, city-regions, agglomerations), there are between 24 and 28 urban giants with over 8 million inhabitants, with Tokyo being the biggest with over 25 to 28 million dwellers.

What is perhaps more interesting than the sheer size of mega-cities is their speed of growth. Cities or urban agglomerations with more than 5 million inhabitants that are to increase their population by more than 50\% between 1996 and 2015 are situated mainly in Asia (Mumbai, Dhaka, Karachi, Delhi, Metro Manila, Jakarta, Lahore, Madras and Bangalore). The same is to occur in Africa, in Lagos. The latter will more than double its population from 11 million in 1996 to approximately 25 million in 2015 [1].

The result of ongoing urban growth is the emergence of metropolises of unprecedented size whose impact on regional, national and global levels is almost unconceivable.

\section{How big can cities grow?}

Thus, the question of how large can cities become arises. The aforementioned projections are valid until 2015/2030. But what can be expected after that? Will the metropolisation of the Blue Planet continue? Will our children see cities, say Gigapolises, of 50 million and more? Or will the biggest cities be able to stabilize their size in the near future and allow smaller cities to become new million or mega-cities?

Another time-honoured question has to be added. How many people can live on planet Earth [5], that is, in cities at all? Are there limits to urban growth? 
Before year 2020, for example, there will be 5 billion urban residents who will not be able to feed themselves. They depend on supplies from rural areas. If farmers continue to give up the production of food in order to migrate to the cities, who will then feed the urban dwellers? Malthus [6] points out that catastrophe can be avoided if mankind perceives the warning signs and if the necessary actions are undertaken in time. So, where are the warning signs?

Anti-Malthusians, like Julian Simon, claim that humans adapt to the problems they create by improvements in productivity and efficiency [7]. According to Simon, the substitutability of resources is infinite and the human population can continue to grow forever. Thus, the key problem is not that resources will run out but that at present, brainpower is not used enough in order to deal with the problems of food security, energy production and so forth.

Bartlett [8] states that we are already living at our limits. His 'First Law' relating to sustainability points out that "Population growth and / or growth in the rates of consumption of resources cannot be sustained". Also, "Growth in the rate of consumption of a non-renewable resource, such as fossil fuel, causes a dramatic decrease in the life-expectancy of the resource" ('Seventh Law'). His 'Second Law' states "In a society with a growing population and / or growing rates of consumption of resources, the larger the population, and / or the larger the rates of consumption of resources, the more difficult it will be to transform the society to the condition of sustainability ... [Thus] Sustainability requires that the size of the population be less than or equal to the carrying capacity of the ecosystem for the desired standard of living" ('Fifth Law'). Bartlett summarizes, "... in order to move toward a sustainable society, the first and most important effort that must be made is to stop population growth" [8].

The point of this chapter is not to judge who is right, Malthus and Bartlett, or Simon. Rather, important questions need to be asked: If what they say is true, what must be done? How can we avoid catastrophes, stop population growth, substitute finite resources? Does technology allow another quantum leap toward the next 'green revolution'? If not, how can substitutes be produced, by whom, on what soil and with what kind of investment?

O'Meara [9] shows examples of how cities can adapt their consumption to realistic needs, produce more own nutrition and energy, and reuse waste more effectively. Also, von Weizsäcker et al. [10] claim that resources like energy and land, for instance, could be used four times more efficiently if human behaviour would change. Daly [11] adds that sustainable development may only be possible if materials are recycled to the maximum degree possible, and if the annual material output of the economy would not grow. But how far can more efficiency and recycling outweigh the future population growth? How can we avoid that bigger populations will not consume more finite resources?

Urban growth not only impacts nutritional and energetic, hydrologic, and atmospheric resources but also land resources and functions of the less densely settled hinterland. The growing cities eat up the land that feeds them. Keywords in this context are urban sprawl, sub-urbanization, pressure on woodland, depletion of biotopes, and impoverishment of the sink and buffer functions of surrounding rural areas. As McGranahan and Satterthwaite point out: "The goal 
is not sustainable cities but cities that contribute to sustainable development within their boundaries, in the region around them, and globally" [12]. Thus, the governments of urban centres should be concerned about the impact of the city on the region and behave in a sustainable way even if the outlying territories cannot be spared from the effects of the city's waste and pollution.

Focus must be laid upon the carrying capacity of the planet Earth and of its highly urbanized regions. The 'carrying capacity' of our planet is defined as the largest number of any given species (human) that a habitat can support indefinitely. 'Indefinitely' means without damaging the environment, that is, the resource basis [13]. Pimentel [14] claims that already in 1998, the global population exceeded the Earth's carrying capacity. Have we already passed the outer limits to global urban growth? How big can an individual city-region become, and how many of them can be supported in each of the world's regions?

Food availability is not the only criterion. The ability to be governed, or governability, is another. Whereas it does not seem very surprising that institution and infrastructure are overburdened for both of the Latin American cities $[15,16]$, one might be astonished to see that even the major metropolitan area of the 'world city' [17] and 'global city' [18] Tokyo is judged to be beyond governance ability $[19,20]$.

Is there a critical size of cities beyond which the authorities cannot keep up with the development? Due to the huge size and the multitude and complexity of problems involved, achieving sustainable development in the mega cities of the developing part of the world seems to be a Sisyphean task.

\section{Governability, density, vulnerability, and migration}

Will mega cities and smaller but rapidly growing cities become more manageable, more liveable, environmentally sounder and safer? The answer is obvious. Some are already borderline ungovernable and it is difficult to imagine how they could make a U-turn from unsustainable to sustainable development. For Bartlett, 'urban growth management' or 'smart growth' are pseudo solutions: "Whether the growth is smart or dumb, the growth destroys the environment", adding that the term sustainable growth would then be an oxymoron [8].

An issue to highlight is governance capacity. There are large cities that have been run well, have overcome environmental challenges, and are increasingly clean, as there are smaller cities that are poorly managed and have terrible living conditions. Indeed, some have argued that it is neither the size of the city nor the speed of growth that is most important in explaining poor urban environments, but that the main culprit is a lack of good governance [21, 22]. Prud'homme [23] points out that mega cities, if well managed, are more productive than smaller cities because the relationship between urban benefits and urban costs is more favourable in larger cities: "A small city poorly managed is bad, a large city poorly managed may be as good (or as bad) as a small city well managed, but a large city well managed is definitely best" [23].

Big cities are probably more difficult to manage than smaller cities. However, Hall and Pfeiffer [24] point out, "...some of the biggest problems occur in 
relatively small cities." In fact, not only mega cities have mega problems. What counts is the governability, that is, the management skills to cope with the problems of growth [2]. Thus, attention must also be given to smaller cities. In 2000 , there were 22 cities with 5 to 10 million people, 370 cities with 1 to 5 million, and 433 cities with 0.5 to 1 million inhabitants. It is estimated that in year 2015 already, there will be worldwide about 564 cities with more than one million inhabitants [25], and the sharpest increase in new million cities will occur in the less developed regions.

While they are growing, cities sharpen inner segregation along income and cultural lines, multiply the coordination tasks for planning, and create more urban diversity. Higher densities may propose gains in economical and cultural terms but can become cumbersome in terms of administration, social care, environmental protection, and control.

The larger cities grow, the higher the urban densities become and the more they become vulnerable to natural hazards (earthquakes, volcanism, etc.), accidents, and terrorism. Eight of the mega-cities in the developing world border an Ocean. Already today, regular flooding catastrophes destroy settlements and life in countries like Bangladesh. If sea levels rise just a few centimetres due to global change, the risks for the crowded populations in those cities will increase, too. Rural areas of food production will suffer as well. Many of the world's big cities are located near fault zones, where damaging earthquakes have taken place in the past (for example, Jakarta, Mexico City, and Teheran). Such cities are at great risk.

Countermeasures have to be adopted before it is too late. Safe environments depend on social cohesion and on their affordability. The future sufficiency of resources depends on their accessibility. As resources and money are concentrated in the developed world, poor countries cannot count on importing needed raw materials, goods and nutrition. Future population growth will mainly take place in the urban areas of developing countries, where money is scarce. Already today, one third of the people living in developing countries, live in slums or squatter settlements. Over $50 \%$ of the global population lives on less than $\$ 2$ per day [26]. Thus, the global welfare divide will increase. Will intragenerational solidarity be established one day? Will resources, knowledge, and technology become equally (according to the needs) distributed between North and South? We are far from an ideal world.

A survival strategy for urban dwellers of the South could be to migrate to less polluted and less problem charged city-regions in the North. But will the cities in the North really become more open ('PubliCities') for migrants from the disadvantaged parts of the globe? There are a lot of obstacles and fears. Where migrations are possible, problems of integration in multicultural and multiracial societies occur [27].

\section{Sustainable urbanization?}

The solutions have to be found not only on a global, but also on a local scale. The challenge for more than half of world's population is to be at the same time 
'homo urbanus' and 'homo sustinens'. The task for urban management is to create urban 'sustainotopes' where the needs of the urbanites are met without compromising the quality of life and resources in the rural areas, today and in the future.

The gap between city and its hinterland, that is, the impacts of the urban area on the rural areas have to be considered. Cities are no isolated islands. Their impact is at least regional, mostly national, and sometimes global. To become sustainable, the cities have to act on all three levels, as well as for themselves.

There are several definitions for 'sustainable cities'. The Institute for Sustainable Communities offers an action-oriented definition as follows: "Sustainable communities are defined as towns and cities that have taken steps to remain healthy over the long term. Sustainable communities have a strong sense of place. They have a vision that is embraced and actively promoted by all of the key sectors of society, including businesses, disadvantaged groups, environmentalists, civic associations, government agencies, and religious organizations. They are places that build on their assets and dare to be innovative. These communities value healthy ecosystems, use resources efficiently, and actively seek to retain and enhance a locally based economy. There is a pervasive volunteer spirit that is rewarded by concrete results. Partnerships between and among government, the business sector, and non-profit organizations are common. Public debate in these communities is engaging, inclusive, and constructive. Unlike traditional community development approaches, sustainability strategies emphasize: the whole community (instead of just disadvantaged neighbourhoods); ecosystem protection; meaningful and broad-based citizen participation; and economic self-reliance" [28].

Urbanization in developing countries today may lead to local clusters of entrepreneurial enterprise, so-called 'economies of agglomeration' with significant cost advantages for the private sector and for the supply of public services. For example, in compact cities the efficiency of infrastructure investments is increased. The most outstanding aspects of agglomeration economies that benefit from the proximity between producers, suppliers, consumers, and workers are:

- The size of an urban labour market allows for the availability of an adequate and relatively inexpensive workforce, and enhances the division and diversification of labour with new job opportunities;

- The access of the firms to a relatively large urban market without long transportation paths, opportunities for specialization and for innovations as well as the ability to react to changes in consumer's demands and potentials for sharing common inputs (warehousing, power etc.).

In 1989, according to the World Bank, about $60 \%$ of the GDP of the developing countries was created in cities, and $80 \%$ of future GDP growth is expected to occur there [29]. Other related benefits of urbanization that accrue directly to the people include, for example, issues of education, interaction, and transfer of know-how. Thus, big cities can be centres of culture and 'social advancement'. These opportunities have to be seized by urban management and planning. 


\section{Good governance and planning for fast growing cities}

The future task and main challenge for the management and steering of mega cities and hyper-expanding medium-sized cities will be to make the turn around from a fast growing urban area with growing problems to a sustainable developing city. The main challenge for sustainable urban development is to establish good governance.

'Good governance,' according to the United Nations Economic and Social Commission for Asia and the Pacific (UNESCAP), has the following characteristics: "It is participatory, consensus oriented, accountable, transparent, responsive, effective and efficient, equitable and inclusive and follows the rule of law. It assures that corruption is minimized, the views of minorities are taken into account and that the voices of the most vulnerable in society are heard in decision-making. It is also responsive to the present and future needs of society" [30].

For rapidly growing cities in the developing world urban development planning towards sustainability is of top priority. These cities must orient their planning and development management towards the predictable future. In so doing, inevitable problems can be at least reduced, the management of metropolitan areas can be improved, and opportunities for more sustainable future development can be made.

Keiner [31] points out five specific fields of action: decentralisation, visions, participation, planning and networking.

- Decentralization. One main aspect is the vertical distribution of power and competences between the national (central) government and its different territorial components, including the cities. Perhaps the biggest tasks in this sense are to cope with the horizontal overlapping of functions and with the high degree of centralization of decision-making. Decentralization is a must for sustainable development [2]. Moreover, urban policy and planning requires a clear distribution of functions and competences.

- Visions. More emphasis has to be laid upon a clearer definition of what is sustainable urban development in the specific context of each city concerned. After fixing the objectives, the way to achieve them should be traced. In order to do so, a comprehensive strategy for sustainable urban development should be worked out.

- Participation. Sustainable urban development requires citizen participation [32, 33], and the democratization of planning decisions [34]. To this end, innovations from the grassroots level have to be promoted [35].

- Planning. An approach for offering more future opportunities for living could be made in spatial planning. Spatial planning is the discipline that steers the development of our present and future living space. In many countries, the implementation of sustainable development via spatial planning has been mandated. The guiding principles of spatial planning should be oriented towards the concept of sustainability. Planning 
instruments should be reshaped in order to create more environmental, economical and societal opportunities. Compacting the cities is a must if their sprawl is to be stopped.

Urban policies are applied through a set of planning instruments and by-laws that range from the regulation of land use to the definition of public and private transportation systems. In order to achieve the desired development as outlined in visions and strategies, the following requirements exist:

- Plans must be oriented toward the objectives of the conceptual framework (i.e., focused on sustainable development)

- Plans and by-laws on urban development should not contradict other plans, strategies and legal regulations

- Plans should cover the "right" spatial perimeter, that is, they should not just consider the cities in their administrative boundaries, but also their interaction with rural regions should be taken into account.

As urban areas spread and consume land, the agricultural areas must be protected. Indicator based monitoring and controlling systems are appropriate tools to steer the development of urban growth and its impact on rural areas, into the desired direction [36].

- $\quad$ Networking. Generally speaking, city to city networking aims at putting together knowledge, creating synergies, and using resources more efficiently. Networking cities are looking for collaboration with other communities, which have similar tasks that can be done more easily, more cheaply and more successfully if jointly undertaken. Networking does not require a spatial connection, it can be a-territorial, that is, virtual (internet) and global. Also, cooperation between science and urban practice plays a key role in finding solutions for sustainable urban development.

\section{Conclusion: good governance for fast growing cities}

Big cities are on the way to becoming gigapolises, if no trend reversal of the current development occurs. Smaller cities will become big cities, too. All of them consume more and more resources and overstep the local, regional, and global carrying capacity. It is clear that the uncontrolled growth of population and urban areas cannot continue. Sustainable development is an answer, but the implementation of this concept into policy tends to come late. To make this vision for the urban future of mankind real, good governance and improved urban management can avoid that mega-cities become victims of Malthusian scenarios in the next future. Action is needed for the smaller, but rapidly growing cities of developing countries, where the main problems and challenges of humanity, today and tomorrow, occur.

As a result, good governance in mega and medium-sized cities in the developing world is a must. This includes, among others, the responsible use of resources, decentralization, and the improvement of the social living conditions of urban dwellers. Also, the growth of populations and cities has to be stopped 
with appropriate measures. Finally, visions for sustainable development should be worked out and put into practice by participatory urban planning.

\section{References}

[1] UN Population Division, The State of World Population, http://www.unfpa.org/swp/ swpmain.htm.

[2] Keiner, M., Salmerón, D. \& Schmid, W.A., Urban development in Southern Africa and Latin America. From Understanding to Action, ed. M. Keiner, C. Zegras, D. Salmerón \& W.A. Schmid, Springer: Dordrecht, pp. 1-24, 2004.

[3] Perlman, J., Mega-cities: Global urbanization and innovation, The MegaCities Project Publication MCP-013, 1993.

[4] Keiner, M. \& Schmid, W.A., Urbanisierungstendenzen in Entwicklungsländern. Probleme und Potenziale für nachhaltige Stadtentwicklung, DISP, 155, pp. 49-56, 2003.

[5] Cohen, J.E., How many people can the Earth support? W.W. Norton \& Company: New York, 1995.

[6] Malthus, T., An Essay on the Principle of Population, http://www.econlib.org/library/Malthus/malPop.html.

[7] Simon, J., The ultimate resource 2, Princeton University Press, 1998.

[8] Bartlett, A.A., Reflections on sustainability, population growth and the environment", Renewable Resources Journal, 15(4), pp. 6-22, 1997.

[9] O’Meara, M., Reinventing cities for people and the planet, Worldwatch Paper 147, Worldwatch Institute, 1999.

[10] Von Weizsäcker, E.U., Lovins, A.B. \& Lovins, L.H., Factor Four; Doubling Wealth - Halving Resource Use, Earthscan: London, 1997.

[11] Daly, H.E., Sustainable Growth: An impossibility theorem. Valuing the Earth: Economics, Ecology, Ethics, ed. H.E. Daly \& K.N. Townsend, MIT Press: Cambridge, 1994.

[12] McGranahan, G. \& Satterthwaite, D., Urban Centres: An Assessment of Sustainability, Annu. Rev. Environ. Resour., 28, pp. 243-274, 2003.

[13] Giampietro, M., Bukkens, S.G.F. \& Pimentel, D., Limits to population size: Three scenarios of energy interaction between human society and ecosystems, Population and Environment, 14, 109-131, 1992.

[14] Pimentel, D., How many people can the Earth support? Population Press, 5(3), 1999.

[15] Molina, L.T. \& Molina, M.J., (eds). Air Quality in the Mexico Megacity, An integrated assessment. Alliance for Global Sustainability Book series Science and Technology: Tools for Sustainable Development, Vol. 2. Kluwer: Dordrecht, Boston, London, 2002.

[16] Santos, M., São Paulo: A growth process full of contradictions. The Mega-City in Latin America, ed. A. Gilbert, UNU Press: Tokyo, New York, Paris, pp. 224-240, 1996.

[17] Friedmann, J., The world city hypothesis. Development and Change, 17, pp. 69-83, 1986. 
[18] Sassen, S. The Global Cities, Princeton: Princeton University Press, 1991.

[19] Takahashi, J. \& Sugiura, N. (1996), The Japanese urban system and the growing centrality of Tokyo in the global economy. Emerging world cities in Pacific Asia, ed. L. Fu-Chen \& Y. Yue-Man, UNU Press: Tokyo, New York, Paris, pp. 101-143, 1996.

[20] Honjo, M., The growth of Tokyo as a world city. Globalization and the world of large cities, ed. L. Fu-Chen \& Y. Yue-Man, UNU Press: Tokyo, New York, Paris, pp. 109-131, 1998.

[21] Satterthwaite, D., Towards healthy cities. People and the Planet, 5(2), 1996.

[22] Gilbert, A., World cities and the urban future: The view from Latin America. Globalization and the world of large cities, ed. L. Fu-Chen \& Y. Yue-Man, UNU Press: Tokyo, New York, Paris, pp. 174-202, 1998.

[23] Prud'homme, R., Managing Megacities. Le courrier du CNRS, 82, pp. 174-176, 1996.

[24] Hall, P. \& Pfeiffer, U., Urban Future 21: A Global Agenda for TwentyFirst Century Cities, Spon Press: New York, 2000.

[25] United Nations (UN), World urbanization prospects - The 1999 revision, UN: New York, 1999.

[26] The World Bank Group, Urbanization \& cities: Facts and figures. http://www.worldbank.org/urban/facts.html.

[27] Sandercock, L., Towards Cosmopolis: Planning for Multicultural Cities, John Wiley \& Sons: New York, 1997.

[28] Institute for Sustainable Communities, Definitions of a sustainable community. http://www.iscvt.org/ FAQscdef.htm.

[29] Perlman, J., Hopkins, E. \& Jonsson, A., Urban solutions at the poverty/environment intersection, The Mega Cities Project Publication MCP-018, 1998.

[30] United Nations Economic and Social Commission for Asia and the Pacific (UNESCAP), What is good governance? http://www.unescap.org/huset/gg/governance.htm.

[31] Keiner, M., Towards Gigapolis? From Urban Growth to Evolutionable medium-sized cities. Managing urban futures: Sustainability and urban growth in developing countries, ed. M. Keiner, W.A. Schmid \& M. KollSchretzenmayr, Ashgate Publishers: Aldershot, pp. 219-232, 2005.

[32] Douglass, M. \& Friedmann, J., (eds). Cities for citizens: planning and the rise of civil society in a global age, John Wiley \& Sons: Chichester (UK), 1997.

[33] Holston, J., Cities and citizenship, Duke University Press: Durham, 1999.

[34] Sandercock, L., Practicing Utopia: Sustaining cities. DISP 148, pp. 4-9, 2002.

[35] Douglass, M., Urban environmental management at the grass roots. Toward a theory of community activation, East-West Center Working Papers, 42: Honolulu, 1995.

[36] Keiner, M., Indicator based control of regional planning. Australian Planner, 39(4), pp. 205-210, 2002. 